\title{
Effects of selected fungicides on in vitro spore germination and vegetative growth of Ascosphaera aggregata
}

\author{
MS Goettel, GM Duke, GB Schaalje, KW Richards
}

Agriculture Canada Research Station, PO Box 3000, Main, Lethbridge, Alberta, Canada TIJ 4B1

(Received 8 August 1991; accepted 13 April 1992)

\begin{abstract}
Summary - Five fungicides were studied for their in vitro effects on spore germination and vegetative growth of Ascosphaera aggregata, the causative organism of chalkbrood in the alfalfa leafcutter bee, Megachile rotundata. The compounds were incorporated directly into liquid or agar growth medium. $\mathrm{EC}_{50}$ s for inhibition of vegetative growth on an agar surface were estimated as follows: enilconazole, 0.034; Rovral (iprodione), 1.10; Benlate (benomyl), 1.16; and Ascocidin ( $\mathrm{N}$-glycosylpolifungin), $135.6 \mathrm{ppm}(\mathrm{m} / \mathrm{v})$. DFMO ( $\alpha$-DL-difluoromethyl ornithine) stimulated growth resulting in an approximately $50 \%$ increased radius at $10000 \mathrm{ppm}$ compared to the control. Benlate inhibited spore germination; at the highest concentration only, Rovral inhibited germination while Ascocidin and enilconazole exhibited a slight effect. DFMO did not affect spore germination. Ascocidin and Benlate exhibited most effect on germling viability at $48 \mathrm{~h}$ followed by Rovral and enilconazole. DFMO had no effect on germling viability. Benlate, Rovral and enilconazole had the most pronounced effect on germ tube growth at $96 \mathrm{~h}$. Ascocidin affected germ tube growth at the higest concentration; DFMO exhibited little to no effect. Comparisons between in vitro results obtained in the present study with previously published in vivo results indicate that in vitro effects on spore germination most closely correlated with efficacy against chalkbrood in vivo, suggesting that compounds with activity against spore germination or germling viability may be the most promising candidates for use against chalkbrood.
\end{abstract}

Ascosphaera aggregata / Megachile rotundata / chalkbrood / chemical control / fungicide

\section{INTRODUCTION}

The alfalfa leafcutter bee, Megachile rotundata $(F)$, is an important pollinator of seed alfalfa in North America. Chalkbrood, a disease caused by the fungus Ascosphaera aggregata Skou is a serious threat to the leafcutter bee industry infect- ing up to $65 \%$ of bees (Kish et al, 1979; Stephen et al, 1981). The disease is spread through use of contaminated nesting materials and by adults that have emerged from chalkbrood-infested material (Vandenberg et al, 1980). Leafcutter bee larvae become infected after consuming $A$ aggregata spores present in con-

\footnotetext{
- Contribution No 3879155 of the Lethbridge Research Station
} 
taminated pollen and nectar provisions (Vandenberg and Stephen, 1982, 1983; McManus and Youssef, 1984).

Present control practices rely principally on the decontamination of nesting materials and bee cells using sodium or calcium hypochlorite (Mayer et al, 1988) or heat (Kish et al, 1979; Stephen, 1982). These practices have provided some control; however, they have not stemmed the spread and increase in levels of the disease, most probably due to the reintroduction of spores from infested feral bee populations (Stephen, 1982).

Considerable effort has been spent searching for a compound which could be incorporated into cell provisions as a prophylactic. Such a compound must be nontoxic to bee larvae, reduce the incidence of chalkbrood, and must not be detrimental to bee behavior or development. Several laboratory and field studies have evaluated fungicides incorporated into the leafcutter bee larval food provisions for chalkbrood control (Parker, 1984, 1985; Youssef and McManus, 1985; Fichter and Stephen, 1987; Parker, 1987, 1988; Youssef and Brindley, 1989; Mayer et al, 1990; Goettel et al, 1991). However, these studies have provided inconsistent and even contradictory results and no compounds have been registered for control of chalkbrood in leafcutter bees. Furthermore, in vivo assays are time-consuming and rely on the presence of leafcutter bee larvae or eggs which are only available in the summer and therefore severely restrict the number of compounds that can be screened in a year.

A possible way of facilitating the search for a suitable compound would be to initially screen numerous compounds for their effects on $A$ aggregata in vitro. Promising agents could then be assayed in vivo. In the present paper we present results of the in vitro effects on $A$ aggregata spore germination and vegetative growth of se- lected fungicides recently studied for their in vivo effects on chalkbrood in leafcutter bees (Goettel et al, 1991). Results indicate that in vitro activity does not necessarily translate to in vivo efficacy in reduction of chalkbrood incidence in learfcutter bees. Compounds with activity against spore germination were most efficacious against chalkbrood.

\section{MATERIALS AND METHODS}

\section{Fungicides, culture media and fungal inoculum}

The compounds used were a $15 \%$ emulsifiable concentrate of enilconazole (Janssen Pharmaceutica), Benlate 50WP (benomyl, El duPont), Rovral 50WP (iprodione, Rhone Poulenc), Ascocidin $(N$-glycosylpolifungin, Warsaw Biotechnical Research and Development Center), and DFMO ( $\alpha$-DL-difluoromethyl ornithine, MerrellDow). Appropriate serial dilutions of fungicide were added to sterile Sabouraud dextrose broth (SDBY) with $2 \%$ yeast extract supplemented with streptomycin $\left(50 \mu \mathrm{g} \cdot \mathrm{ml}^{-1}\right)$ and penicillin (25 $\mathrm{IU} \cdot \mathrm{ml}^{-1}$ ) to obtain final fungicide concentrations of between 0.5 and $1000 \mathrm{ppm}(\mathrm{m} / \mathrm{v})$ as required. Fungicides were also incorporated into Sabouraud dextrose agar with $2 \%$ yeast extract (SDAY) by suspending the chemical in $1 \mathrm{ml}$ of sterile distilled water, which was then added to sterile SDAY. Serial dilutions were performed on constantly stirred warm media, then pipetted into $60 \times 15 \mathrm{~mm}$ Petri plates.

Leafcutter bee cells from a 1989 population of bees near Brooks, Alberta with a $15 \%$ incidence of chalkbrood were supplied by the Canadian Alfalfa Leafcutter Bee Cocoon Testing Centre, Brooks, Alberta. Cadavers were removed from the cells and spores of $A$ aggregata were harvested as follows. Up to 50 cadavers and a magnetic stirrer bar were placed onto the surface of a concave fine mesh plastic screen (12 squares' $\mathrm{cm}^{-1}$ ) which was built by glueing the screen onto a $1.5 \mathrm{~cm} \times 8.5 \mathrm{~cm}$ diameter plastic ring. The ring was then placed in a $9 \mathrm{~cm}$ diameter glass Petri dish, covered, sealed with Parafilm and placed on a magnetic stirrer. Cadavers were stirred until all ascomata were scraped off 
the surface. The spores were collected from beneath the screen and were kept sealed at $4{ }^{\circ} \mathrm{C}$ until needed.

Spore suspensions were prepared by combining spores with a drop of SDBY and crushing between 2 sterile glass slides to eliminate spore balls. Spores were then suspended in SDBY in a sterile microcentrifuge tube and spore concentrations were determined using an improved Neubauer hemocytometer. The inoculum for the vegetative growth assays was prepared by purging a 200- $\mu$ l spore suspension in a microcentrifuge tube with $\mathrm{CO}_{2}$ from a pressurized gas cylinder and incubating at $30{ }^{\circ} \mathrm{C}$ for $12 \mathrm{~h}$. The germinated spores were spread on SDAY plates supplemented with cycloheximide $\left(30 \mu \mathrm{g} \bullet \mathrm{ml}^{-1}\right)$, streptomycin $\left(50 \mu \mathrm{g} \bullet \mathrm{ml}^{-1}\right)$ and penicillin (25 IU.m| $\left.\right|^{-1}$ ) in order to inhibit growth of bacteria and black yeast-like fungi (Trichosporonoides $\mathrm{sp}$ ) which are a frequent contaminant in spores (unpublished observations). Single isolated germlings were later transferred to SDAY plates not supplemented with antimicrobial compounds and incubated at room temperature.

\section{Vegetative growth assays}

SDAY plates containing various concentrations of test fungicides were inoculated with a $5-\mathrm{mm}$ inverted plug of $A$ aggregata obtained from the periphery of 4-5-day-old cultures. The plates were sealed with Parafilm and randomly placed in a container which was incubated at $28^{\circ} \mathrm{C}$ and a daily photoperiod of $16 \mathrm{~h}$ light $8 \mathrm{~h}$ dark for 2 weeks. Measurements of growth were made by averaging the minimum and maximum radiuses of mycelial growth on each plate, minus the width of the inoculum plug. An initial trial used 5 concentrations of each fungicide and a control, non-fungicide treated culture medium with 10 replicate plates for each treatment. An additional trial used adjusted fungicide concentrations as necessary.

\section{Spore germination, germling viability and growth assays}

Spores were germinated in liquid media containing various concentrations of fungicide; spore germination was measured at $24 \mathrm{~h}$ and germling viability was measured at 48,72 , and $96 \mathrm{~h}$ using a vital dye; germling lengths were measured at $96 \mathrm{~h}$ as follows. Spores from a stock suspension in SDBY were added to $100 \mu$ of SDBY containing either $0,0.1,1,10$ or $100 \mathrm{ppm}(\mathrm{m} / \mathrm{v})$ of fungicide in $1.5 \mathrm{ml}$ microcentrifuge tubes to obtain final concentrations of $1 \times 10^{6}$ spores $^{\circ} \mathrm{m}^{-1}$. Tubes were purged with $\mathrm{CO}_{2}$, wrapped with Parafilm and incubated at $30^{\circ} \mathrm{C}$ for $24 \mathrm{~h}$. Spore germination rates were determined by counting numbers of germinated versus non-germinated spores. Tubes were then returned to the incubator. At 24-h intervals thereafter, germling viability was measured using fluorescein diacetate (FDA) (Soderstrom, 1977); a stock solution of FDA containing $1 \mathrm{mg}^{\circ} \mathrm{ml}^{-1}$ acetone was used to produce a working solution of $5 \mu \mathrm{l}$ of stock FDA $\mathrm{Fm}^{-1}$ deionized water. Viability assessments were performed by combining $5 \mu$ l FDA working solution with an equal amount of fungal suspension on a glass slide; slides were then examined with a Nikon Optiphot fluorescence microscope using a dichroic mirror of $510 \mathrm{~nm}$, excitation filter of 450 $490 \mathrm{~nm}$ and a barrier filter of $520 \mathrm{~nm}$. Percent viability was determined by counting the number of fluorescing germlings versus the total number of spores and germlings observed at $400 x$ in the same field of view using phase contrast microscopy. Germ tube lengths of the 10 longest germ tubes in 10 fields of view were measured using an ocular micrometer. Germ tube lengths were measured from 1 replicate only.

Initially the experiment used one tube per treatment testing all fungicides at the 4 concentrations on the same day and was repeated 4 times. Large variability in results, in part due to contamination with Trichosporonoides sp, made meaningful analysis of the germination and viability data not possible. As replicating treatments testing all fungicides in one experiment was precluded due to the time required for the viability determination, the experiment was repeated using 4 replications of 4 concentrations of a specific fungicide; each fungicide was tested on a separate day and included a control. Germination rates were then corrected for controls as described below.

\section{Statistical analyses}

The vegetative growth assay data for all fungicides except DFMO were analyzed by fitting the nonlinear model : 


$$
r=\frac{\alpha e^{-\beta i(\sigma-\mu i)\left(c-\mu_{i}\right)}}{1+e^{-\beta i\left(\sim \mu_{i}\right)}}
$$

where $r$ is the observed radius, $e$ is the base of natural logarithms, $c$ is the concentration of the fungicide, and $a, \beta_{i}$, and $\mu_{i}$ are parameters to be estimated. The parameter $\alpha$ is the maximum achievable radius for all fungicides, $\mu_{\mathrm{i}}$ is the natural logarithm of the $\mathrm{EC}_{50}$ (effective concentration for $50 \%$ reduction in radius) for fungicide $i$ and $\beta_{i}$ is a coefficient determining the rate of decline of the curve for fungicide $i$. The data for all fungicides as well as the control data were fitted simultaneously. The control data were used only to estimate $\alpha$. Weighted nonlinear regression via the NLIN procedure of SAS was used to fit the function, estimate the parameters and their standard errors, and test for differences among the $\log \left(\mathrm{EC}_{50}\right)$ values.

Untransformed spore germination data were analyzed using an ANOVA model that included effects for fungicide, concentration, and their interaction. Significant and often large differences among the control treatments for each fungicide indicated that the data needed to be corrected for daily variation in germination rates. Corrected average germination rates for concentration $j$ of fungicide $i$ were computed as :

$$
g_{i j}^{\prime}=g_{i j}^{\prime} / g_{i o}
$$

where $g_{i j}^{\prime}$ is the corrected germination rate, $g_{i j}$ is the observed germination rate averaged over replicates, and $g_{i o}$ is the observed average germination rate for the control replicates run on the same day as fungicide $i$. Pairwise comparisons of corrected germination rates among fungicides ( $i$ and $k$ ) for each concentration $(j)$ were carried out by dividing the value of :

$$
\log \left(g_{i j}^{\prime} / g_{k j}^{\prime}\right)
$$

by its approximate standard error, and evaluating the ratio at the 0.01 level using the normal distribution. The standard error was obtained using the delta method (Rao, 1973) and the residual mean squared error from the ANOVA.

Forty-eight hour germling viability data were transformed using the arcsin-square root transformation to achieve variance homogeneity, and analysed using an ANOVA model that included effects for fungicide, concentration, and their in- teraction. Because the DFMO data were all close to $100 \%$ viability with little variability, they were not included in the analysis. The control treatments for each of the fungicides were not significantly different; therefore no correction was applied to the viability rates. Pairwise comparisons of viability rates among fungicides for each concentration were carried out using the least significant difference procedure at the 0.01 level of significance.

Mean germ tube lengths were computed, but could not be compared statistically because only one replicate (tube) was available per fungicideconcentration combination. For a rough guideline, pairwise differences between fungicides were denoted as being 'significant' in table II if the difference between their mean germ tube lengths was over 3 times greater than the standard error of their difference (computed using their respective within-tube variances).

\section{RESULTS}

\section{Vegetative growth assays}

The effects of fungicide concentrations on vegetative growth are summarized in figure 1. Using the logistic function, $E_{50} \mathrm{~s}$ in ppm (confidence limits) were estimated as follows: enilconazole, $0.034 \quad(0.0262$, $0.0435)$; Rovral, 1.10 (0.767, 1.588); Benlate, $1.16(0.214,6.278)$; and Ascocidin, 135.6 (76.96, 238.79). DFMO stimulated growth resulting in an approximately $50 \%$ increased radius at $10000 \mathrm{ppm}$ compared to the control.

\section{Spore germination, germling viability and growth assays}

The effects of fungicide concentration on spore germination at $\mathbf{2 4} \mathrm{h}$ are summarized in figure 2. The maximum dose tested was $100 \mathrm{ppm}$ because higher concentrations of the wettable powders obscured viewing of 


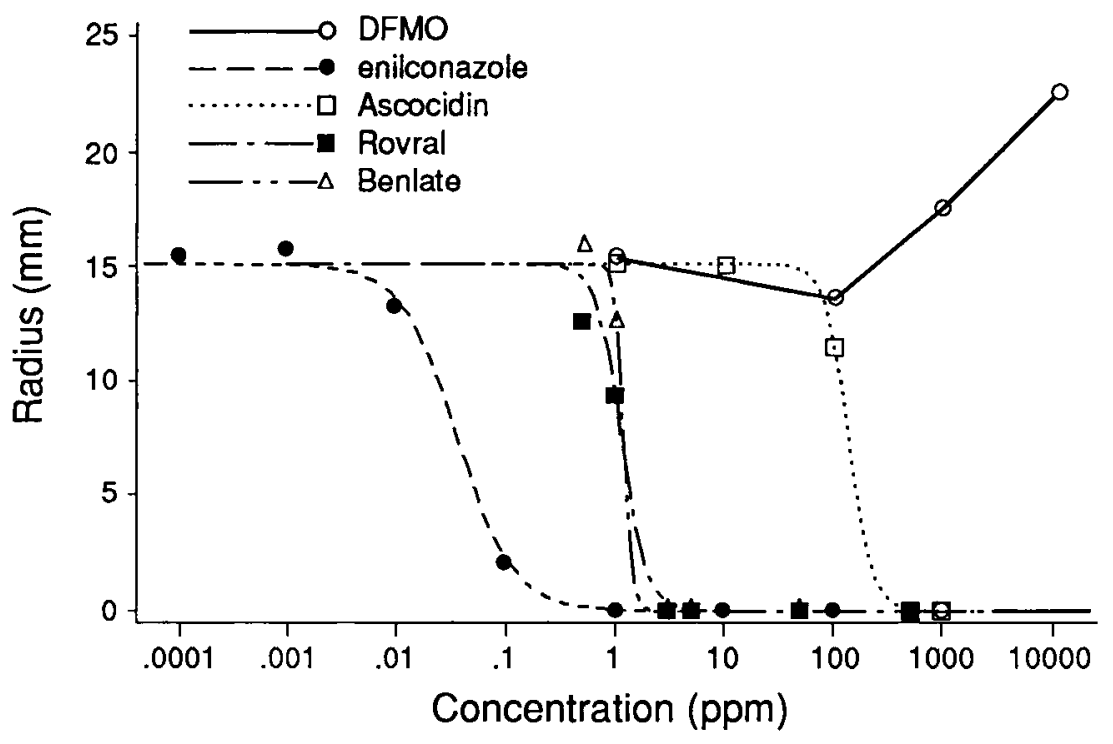

Fig 1. Effects of selected fungicides on vegetative growth of Ascosphaera aggregata grown for 2 weeks on SDAY at $28^{\circ} \mathrm{C}$.

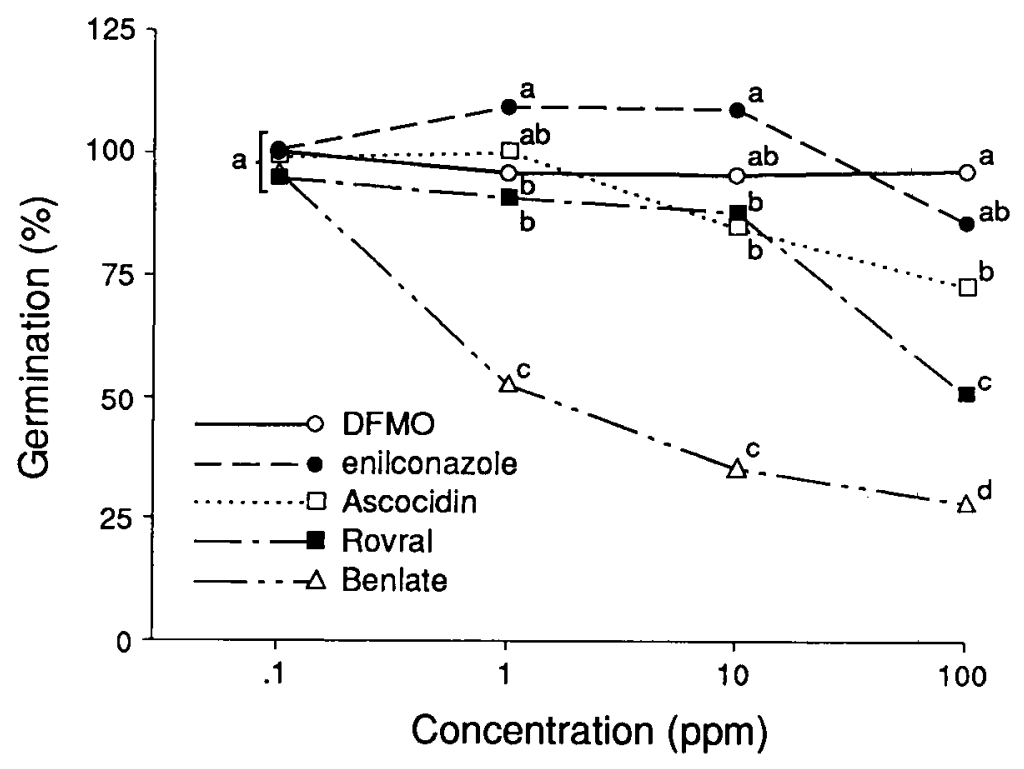

Fig 2. Effects of selected fungicides on Ascosphaera aggregata spore germination after $24 \mathrm{~h}$ at $30^{\circ} \mathrm{C}$ in SDBY and treated with $\mathrm{CO}_{2}$. Germination rates were corrected for control treatments. 
the spores and therefore made germination and viability assessments not possible. Benlate inhibited spore germination; at the highest concentration only, Rovral inhibited germination, while Ascocidin and enilconazole exhibited a slight effect. DFMO did not affect germination.

The effects of fungicide concentration on germling viability after $48 \mathrm{~h}$ are summarized in figure 3. Ascocidin and Benlate exhibited most antifungal effect followed by Rovral and enilconazole. DFMO had no effect on viability. Viabilities at 72 and $96 \mathrm{~h}$ showed large variability, in part due to contamination with Trichosporonoides $\mathrm{sp}$; meaningful analysis of the data was not possible and these data are not presented.

The effects of fungicide concentration on germ tube growth are summarized in table I. Benlate, Rovral, and enilconazole had the most pronounced effect on germ tube growth. Ascocidin affected germ tube growth only at the highest concentration; DFMO showed little effect.

\section{Comparison between in vivo and in vitro effects}

Ranking of the fungicides according to in vitro and in vivo efficacy reveals that effects on spore germination most closely correlated with efficacy against chalkbrood (table II). The effects of fungicides on vegetative growth on an agar surface gave the most contradictory results as far as comparisons with in vivo effects are concerned; enilconazole was superior on agar whereas it was ineffective against chalkbrood caused by $A$ aggregata in vivo (Goettel et al, 1991).

\section{DISCUSSION}

Comparisons between in vitro results obtained in the present study with in vivo results obtained previously (Goettel et al, 1991 ) indicate that in vitro antifungal activi-

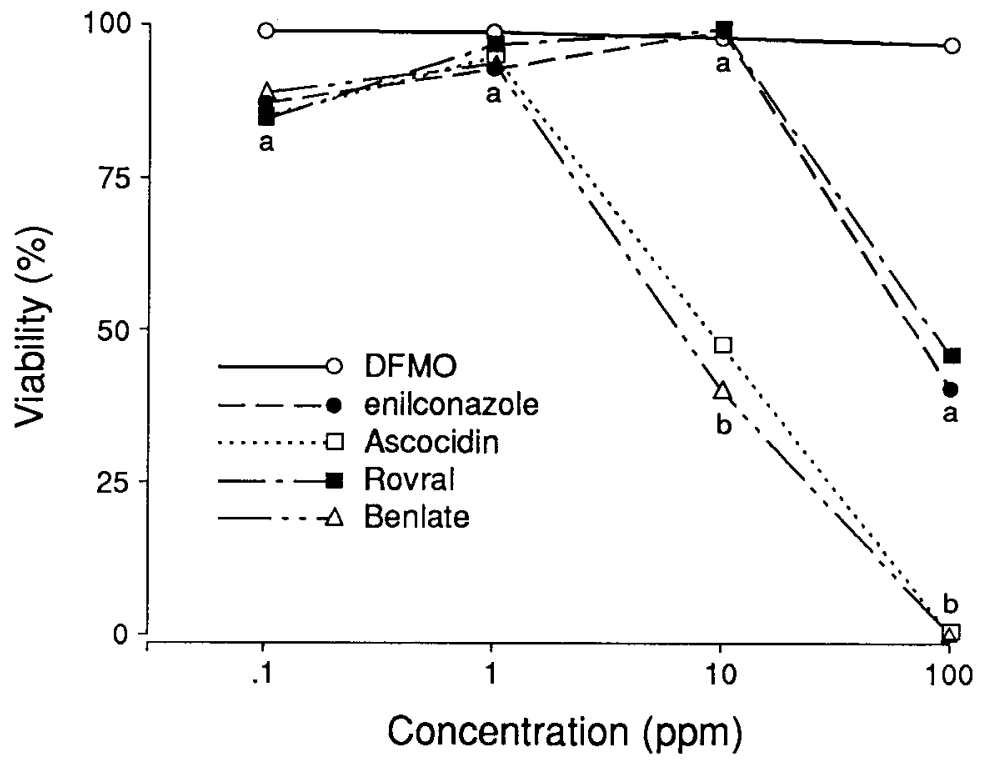

Fig 3. Viability of Ascosphaera aggregata germlings $48 \mathrm{~h}$ after exposure of spores to $\mathrm{CO}_{2}$ and fungicides at $30^{\circ} \mathrm{C}$ in SDBY. Viability was determined using fluorescein diacetate. 
Table I. Effects of selected fungicides on Ascosphaera aggregata germ tube length *.

\begin{tabular}{|c|c|c|c|c|}
\hline \multirow{2}{*}{$\begin{array}{l}\text { Fungicide } \\
\text { time }(h)\end{array}$} & \multicolumn{4}{|c|}{ Concentration (ppm) } \\
\hline & 0.1 & 1 & 10 & 100 \\
\hline \multicolumn{5}{|l|}{ Benlate } \\
\hline 72 & $60.8 \pm 3.43$ & $21.8 \pm 1.38$ & $6.0 \pm 0.00$ & $5.4 \pm 0.16$ \\
\hline 96 & $117.8 \pm 3.74$ & $97.6 \pm 3.96$ & $6.0 \pm 0.00$ & $4.8 \pm 0.25$ \\
\hline \multicolumn{5}{|l|}{ Rovral } \\
\hline 72 & $77.8 \pm 6.08$ & $13.4 \pm 1.93$ & $7.5 \pm 0.22$ & $5.5 \pm 0.22$ \\
\hline 96 & $80.2 \pm 6.35$ & $14.8 \pm 1.16$ & $7.1 \pm 0.23$ & $5.6 \pm 0.16$ \\
\hline \multicolumn{5}{|c|}{ Enilconazole } \\
\hline 72 & $33.6 \pm 3.83$ & $17.8 \pm 0.76$ & $11.2 \pm 1.27$ & $5.9 \pm 0.18$ \\
\hline 96 & $66.6 \pm 2.65$ & $21.6 \pm 0.50$ & $9.7 \pm 0.60$ & $5.9 \pm 0.10$ \\
\hline \multicolumn{5}{|l|}{ Ascocidin } \\
\hline 72 & $79.4 \pm 6.17$ & $61.0 \pm 3.89$ & $57.2 \pm 7.95$ & $7.1 \pm 1.20$ \\
\hline 96 & $168.0 \pm 4.08$ & $143.6 \pm 9.36$ & $128.8 \pm 9.30$ & $53.8 \pm 4.71$ \\
\hline \multicolumn{5}{|l|}{ DFMO } \\
\hline 72 & $42.8 \pm 2.00$ & $45.4 \pm 3.72$ & $45.2 \pm 1.66$ & $108.6 \pm 3.31$ \\
\hline \multirow[t]{2}{*}{96} & $141.0 \pm 6.18$ & $101.0 \pm 6.01$ & $91.0 \pm 3.03$ & $94.4 \pm 2.96$ \\
\hline & & 0 (control) & & \\
\hline \multicolumn{5}{|l|}{ Control } \\
\hline 72 & & $93.0 \pm 5.47$ & & \\
\hline 96 & & $161.6 \pm 6.64$ & & \\
\hline
\end{tabular}

- Mean length in microns of 10 longest germ tubes of $A$ aggregata spores treated with $\mathrm{CO}_{2}$ and incubated at $30^{\circ} \mathrm{C}$ in sabouraud dextrose broth containing the fungicide.

Table II. Fungicides ranked according to efficacy against Ascosphaera aggregata.

\begin{tabular}{|c|c|c|c|c|}
\hline In vivo 2 & $\begin{array}{c}\text { Spore } \\
\text { germination }\end{array}$ & $\begin{array}{l}\text { Germling } \\
\text { viability }^{4}\end{array}$ & $\begin{array}{l}\text { Germling } \\
\text { growth }\end{array}$ & $\begin{array}{l}\text { Vegetative } \\
\text { growth }\end{array}$ \\
\hline $\begin{array}{l}\text { Rovral } \\
\text { Benlate } \\
\text { Ascocidin } \\
\text { Enilconazole } \\
\text { DFMO }^{8}\end{array}$ & $\begin{array}{l}\text { Benlate, a } \\
\text { Rovral, b } \\
\text { Ascocidin }{ }^{7} \mathrm{c} \\
\text { enilconazole }{ }^{7} \mathrm{~cd} \\
\text { DFMO }^{8} \mathrm{~d}\end{array}$ & $\begin{array}{l}\text { Ascocidin, a } \\
\text { Benlate, a } \\
\text { Rovral, b } \\
\text { enilconazole, b } \\
\text { DFMO }^{8} \mathrm{c}\end{array}$ & $\begin{array}{l}\text { Benlate, a } \\
\text { Rovral, ab } \\
\text { enilconazole, b } \\
\text { Ascocidin, c } \\
\text { DFMO }{ }^{7 d}\end{array}$ & $\begin{array}{l}\text { enilconazole, a } \\
\text { Rovral, b } \\
\text { Benlate, b } \\
\text { Ascocidin, c } \\
\text { DFMO }{ }^{9} d\end{array}$ \\
\hline
\end{tabular}

${ }^{1}$ Compounds followed by the same letter are not significantly different. Ranking from highest to lowest efficacy. ${ }^{2}$ In vivo efficacy on chalkbrood based on Goettel et al, 1991. ${ }^{3}$ After $24 \mathrm{~h}$ at $30^{\circ} \mathrm{C}$ in SDBY. ${ }^{4}$ After $48 \mathrm{~h}$ at $30{ }^{\circ} \mathrm{C}$ in SDBY determined using fluorescein diacetate. ${ }^{5}$ Maximum germ tube length after $96 \mathrm{~h}$ at $30^{\circ} \mathrm{C}$ in SDBY at 100 ppm. ${ }^{6}$ Colony diameter after 2 weeks growth at $30^{\circ} \mathrm{C}$ on SDAY. ${ }^{7}$ Slight inhibition. ${ }^{8}$ No effect. ${ }^{9}$ Stimulatory effect. 
ty does not necessarily translate to in vivo efficacy in reduction of chalkbrood incidence in leafcutter bees (table II). Among the 5 compounds tested, in vitro effects on spore germination most closely correlated with efficacy against chalkbrood in vivo suggesting that compounds with activity against spore germination or germling viability may be the most promising candidates for use against chalkbrood.

Although the addition of antimicrobials in sensitivity tests should be avoided as they can themselves influence the test microorganism, this could not be avoided with $A$ aggregata as this organism does not sporulate in vitro; spores obtained from chalkbrood cadavers were contaminated with bacteria and a Trichosporonoides sp. Bacteria were adequately controlled with antibacterials; however, as cycloheximide may affect $\boldsymbol{A}$ aggregata, it was not used, and thus Trichosporonoides sp remained a contaminant and this precluded observations after $48 \mathrm{~h}$. Nevertheless, as the results presented are corrected for controls, it would be expected that any nonsynergistic influence due to the addition of the antimicrobials would also be corrected for.

Rovral, Benlate and Ascocidin exhibited efficacy in all in vitro parameters tested (figs 1-3, table 1). Both Rovral and Benlate had previously been shown to reduce chalkbrood incidence in laboratory bioassays (Fichter and Stephen, 1987; Goettel et al, 1991) and in field trials, albeit only marginally (Parker, 1987; Mayer et al, 1990). Ascocidin has not been field-tested against $A$ aggregata; however, it is used in Poland for control of Ascosphaera apis in honey bees (A Hartwig, Warsaw Agricultural University, personal communication).

Enilconazole exhibited only slight sporicidal activity (fig 2), as is characteristic of sterol inhibitors in general (Ragsdale, 1977). Even though it exhibited the highest antifungal activity against vegetative growth on an agar surface (fig 1) and inhibition to germling growth and viability equivalent to Rovral (fig 3; table I), it was not effective against chalkbrood in vivo (Goettel et al, 1991). This suggests that the compound was either inactivated in the gut or was not absorbed into the hemocoel; since this compound does not inhibit spore germination and initial germ tube growth, the fungus could penetrate the gut and escape the antifungal activity.

It was previously demonstrated that DFMO actually increased levels of chalkbrood (Goettel et al, 1991). As DFMO has a wide range of antimicrobial activity (Bitonti and McCann, 1987), this effect was attributed to the inhibition of possible $\mathrm{A}$ aggregata antagonists (Goettel et al, 1991). The results in the present study reveal that DFMO has no effect on spore germination, germling viability and initial germling growth, but it stimulates vegetative growth at higher concentrations. Specific inhibition of ornithine decarboxylase with DFMO inhibits germination, mycelial growth and sporulation of fungi (Slocum and Galston, 1987). The in vitro results with $A$ aggregata suggest that it may possess an alternate or unique pathway for polyamine synthesis or a DFMO insensitive ornithine decarboxylase as has been shown to occur in other organisms (Bitonti and McCann, 1987) and warrants further investigation.

The comparisons between in vitro and in vivo results suggest that activity against spore germination is of paramount importance in efficacy against chalkbrood. Unfortunately, very few compounds have been identified which are sporicidal to $A$ aggregata and could be incorporated into leafcutter bee provisions at concentrations nontoxic to bees (Stephan et al, 1982; Kish and Panlasigui, 1985). Results from the present study suggest that in vitro screening for candidate compounds for control of chalkbrood should pay special attention to 
effects on spore germination and germling viability.

\section{ACKNOWLEDGMENTS}

We thank Janssen Pharmaceutica, Dupont, Rhone Poulenc, A Hartwig, Warsaw Agricultural University, and R St Leger, Boyce Thompson Institute, for providing the fungicides; S Simms of the Canadian Alfalfa Leafcutter Bee Cocoon Testing Centre for providing chalkbrood cadavers; D Gaudet and L Kawchuk for critically reviewing the manuscript. Partial funding for this study was provided by Janssen Pharmaceutica.

\section{Résumé - Action de fongicides sur la} germination in vitro des spores et la croissance végétative d'Ascosphaera aggregata. On a étudié les effets de 5 produits sur la germination in vitro des spores et la croissance végétative d'Ascosphaera aggregata, agent du couvain plâtré de la mégachile, Megachile rotundata. Les 5 produits étudiés étaient : un concentré émulsifiable d'énilconazole à $15 \%$ (Janssen Pharmaceutica), le Benlate 50WP (bénomyl, El duPont), le Rovral 50WP (iprodione Rhône-Poulenc), I'Ascocidin ( $N$ glycosylpolifungin, Centre de Développement et de Recherche Biotechnologique de Varsovie) et le DFMO ( $\alpha$-DLdifluoromethyl ornithine, Merrell-Dow). Des dilutions appropriées en série ont été ajoutées à un bouillon dextrosé (SDBY) ou à une gélose dextrosée de Sabouraud (SDAY) stériles avec un extrait de levure à $2 \%$ afin d'obtenir les concentrations finales en fongicides voulues, comprises entre 0,5 et $1000 \mathrm{ppm}(\mathrm{m} / \mathrm{v})$. Pour les études de croissance végétative, de l'inoculum d' $A$ aggregata a été placé sur des plaques de gélose renfermant diverses concentrations de fongicides et la croissance a été mesurée 2 semaines plus tard. Les effets des fongicides sur la croissance végétative sont résumés dans la figure 1. Les $E_{50}$ (concentration efficace pour une réduction radiale de $50 \%$ ) ont été estimées à 0,034 pour l'énilconazole, à 1,10 pour le Rovral, à 1,16 pour le Benlate ef à 135,6 ppm pour l'Ascocidin. Le DFMO a stimulé la croissance, provoquant un accroissement radial de $50 \%$ à 10000 ppm par rapport au témoin. Pour les tests de germination des spores, de viabilité et de croissance des propagules, les spores ont été mises a germer dans des milieux liquides contenant diverses concentrations de fongicides; la germination des spores a été mesurée à $24 \mathrm{~h}$ et la viabilité des propagules jusqu'à $96 \mathrm{~h}$ avec le diacétate de flurorescéine comme colorant vital; la longueur des propagules a été mesurée à $96 \mathrm{~h}$. Le Benlate a inhibé la germination des spores; à la concentration la plus élevée, seul le Rovral a inhibé la germination, tandis que I'Ascocidin et l'énilconazole ont montré un léger effet (fig 2); le DFMO n'a pas affecté la germination des spores. L'Ascocidin et le Benlate ont été les plus efficaces en ce qui concerne la viabilité des propagules à $48 \mathrm{~h}$, suivis par le Rovral et l'énilconazole (fig 3). Le DFMO n'a eu aucune action sur la viabilité des propagules. Le Benlate, le Rovral et l'énilconazole sont les produits qui ont le plus inhibé la croissance du tube germinatif à $96 \mathrm{~h}$ (tableau 1). L'Ascocidin a inhibé la croissance du tube germinatif à la concentration la plus forte; le DFMO a eu comparativement peu d'effet. La comparaison entre les résultats in vitro présentés ici et les résultats in vivo publiés précédemment (Goettel et al, 1991, Apidologie 22, 509-522) montre que les effets in vitro sur la germination des spores sont les plus étroitement corrélés avec l'efficacité in vivo contre le couvain plâtré (tableau II). Ceci laisse penser que les produits actifs contre la germination des spores ou la viabilité des propagules peuvent être les candidats les plus prometteurs pour lutter contre le couvain plâtré. 
Ascosphaera aggregata / Megachile rotundata / couvain plâtré / lutte chimique / fongicide

\section{Zusammenfassug - Wirkungen ausge-} wähiter Fungizide auf die Sporenkeimung in vitro und auf das vegetative Wachstum von Ascosphaera aggregata. Es wurden fünf Präparate hinsichtlich ihrer in vitro-Wirkung auf die Sporenkeimung und das vegetative Wachstum von Ascosphaera aggregata, dem Erreger der Kalkbrut bei Megachile rotundata studiert. Es handelte sich um folgende Präparate: Enilconazole in einem 15\%igen emulgierbaren Konzentrat (Janssen Pharmaceutica), Benlate 50WP (Benomyl, El DuPont), Rovral 50WP (Iprodione, Rhône Poulenc), Ascocidin (N-Glycosylpolifungin, Warsaw Biotechnical Research and Development Centre), und DFMO ( $\alpha-D L-$ difluoromethyl Ornithine, <Merrell-Dow). Geeignete seriale Verdünnungen der Fungizide wurden steriler, Sabouraud Dextrose-Bouillon (SDBY) oder Agar (SDAY) mit $2 \%$ HefeExtrakt hinzugefügt, um die gewünschten Endkonzentrationen der Fungizide zwischen 0,5 und $1000 \mathrm{ppm}(\mathrm{m} / \mathrm{v})$ zu erzielen. Für die Studien über das vegetative Wachstum wurden Tropfen einer Impfaufschwemmung mit $A$ aggregata auf die Oberfläche von Agarplatten ausgebracht, die Fungizide in verschiedener Konzentration enthielten; das Wachstum wurde nach zwei Wochen gemessen. Der Effekt der Fungizide auf das vegetative Wachstum ist in Abbildung 1 zusammengfaßt. Für $E_{50} s$ der Hemmung des vegetativen Wachstums auf der Agar-Oberfläche ergaben sich folgende Schätzwerte: Enilconazole, 0,034; Rovral, 1,1; Benlate, 1,16; Ascocidin, 135,6 ppm. DFMO stimulierte das Wachstum, wobei sich gegenüber den Kontrollen bei 10000 ppm eine $50 \%$ ige Vergrößerung des Radius ergab. Für die
Sporenkeimung, Lebensfähigkeit der Keimlinge und Wachstumsstudien wurden Sporen in flüssigen Medien mit verschiedenen Konzentrationen der Fungizide zur Keimung gebracht; die Sporenkeimung wurde nach 24 Stunden gemessen und die Lebensfähigkeit der Keimlinge nach einer Zeit von bis zu 96 Stunden bestimmt wobei Fluoreszin-Diazetat als Vitalfärbung benutzt wurde; die Länge der Keimlinge wurde nach 96 Stunden gemessen. Benlate hemmte die Sporenkeimung; Rovral hemmte die Keimung nur in der höchsten Konzentration, während Ascocidin und Enilconazole nur einen geringen Effekt zeigten (Abb 2); DFMO beeinflußte die Sporenkeimung nicht. Ascocidin und Benlate, gefolgt von Rovral und Enilconazole, zeigten die größte Wirkung auf die Lebensfähigkeit der Keimlinge nach 48 Stunden (Abb 3). DFMO zeigte keine Wirkung auf die Lebensfähigkeit der Keimlinge. Benlate, Rovral und Enilconazole waren die Verbindungen mit der stärksten Hemmwirkung auf das Wachstum der Keimschläuche nach 96 Stunden (Tabelle I). Ascocidin hemmte das Wachstum der Keimschläuche bei der höchsten Konzentration; DFMO hatte vergleichsweise geringe Wirkungen. Der Vergleich der Resultate der Laborexperimente der vorliegenden Untersuchung mit früher erzielten Feldversuchen (Goettel et al, 1991, Apidologie 22, 509-522) weist darauf hin, daß die im Labor erzielten Effekte auf die Sporenkeimung am stärksten mit der Wirksamkeit gegen die Kalkbrut im Feldversuch korreliert sind (Tabelle II). Dies läßt darauf schließen, daß Präparate mit Wirksamkeit auf die Sporenkeimung und die Lebensfähigkeit der Keimlinge die aussichtsreichsten Kandidaten für einen Einsatz gegen die Kalkbrut sein könnten.

Ascosphaera aggregata / Megachile rotundata / chemische Bekämpfung / Kalkbrut / Fungizide 


\section{REFERENCES}

Bitonti AJ, McCann PP (1987) Inhibition of polyamine biosynthesis in microorganisms. $/ n$ : $/ n$ hibition of Polyamine Metabolism (McCann PP, Pegg AE, Sjoerdsma A, eds) Academic Press, New York

Fichter BL, Stephen WP (1987) Efficacy of selected fungicides against chalkbrood of the leafcutting bee. J Apic Res 26, 137-143

Goettel MS, Richards KW, Schaalje GB (1991) Bioassay of selected fungicides for control of chalkbrood in alfalfa leafcutter bees, Megachile rotundata. Apidologie 22, 509-522

Kish LP, Panlasigui PM (1985) Effects of selected chemical treatments on spore germination of Ascosphaera aggregata (Ascosphaerales). Environ Entomol 14, 424-426

Kish LP, Waters ND, Homan HW (1979) Chalkbrood. Curr Inf Ser No 477, Univ Idaho Coop Ext Serv Agric Exp Stn, Moscow, ID

Mayer DF, Lunden JD, Kious CW (1988) Effects of dipping alfalfa leaf-cutting bee nesting materials on chalkbrood disease. Appl Agric Res 3, 167-169

Mayer DF, Lunden JD, Miliczky ER (1990) Effects of fungicides on chalkbrood disease of alfalfa leafcutting bee. Appl Agric Res 5, 223226

McManus WR, Youssef NN (1984) Life cycle of the chalk brood fungus, Ascosphaera aggregata, in the alfalfa leafcutting bee, Megachile rotundata, and its associated symptomatology. Mycologia 76, 830-842

Parker FD (1984) Effect of fungicide treatments on incidence of chalkbrood disease in nests of the alfalfa leafcutting bee (Hymenoptera: Megachilidae). J Econ Entomol 77, 113-117

Parker FD (1985) Effective fungicide treatment for controlling chalkbrood disease (Ascomycetes: Ascosphaeraceae) of the alfalfa leafcutting bee (Hymenoptera: Megachilidae) in the field. $J$ Econ Entomol 78, 35-40

Parker FD (1987) Further studies on the use of fungicides for control of chalkbrood of the alfalfa leafcutting bee. J Apic Res 26, 144-149

Parker FD (1988) Influence of wood, paper, and plastic nesting units on efficacy of three candidate fungicides for control of chalkbrood in the alfalfa leafcutting bee (Hymenoptera: Megachilidae). J Econ Entomol 81, 789-795
Ragsdale NN (1977) Inhibitors of lipid synthesis. In: Antifungal Compounds (Sisler HD, Siegel MR, eds) Marcel Dekker, New York

Rao CR (1973) Linear Statistical Inference and its Applications. Wiley, New York, 2nd edn

Slocum RD, Galston AW (1987) Inhibition of polyamine biosynthesis in plants and plant pathogenic fungi. In: Inhibition of Polyamine Metabolism (McCann PP, Pegg AE, Sjoerdsma A, eds) Academic Press, New York

Soderstrom BE (1977) Vital staining of fungi in pure cultures and in soil with fluorescein diacetate. Soil Biol Biochem 9, 59-63

Stephen WP (1982) Chalkbrood control in leafcutting bee. Proc Int Symp Alfalfa Leafcutting Bee Management (Rank GH, ed) Univ of Saskatoon, Saskatoon

Stephen WP, Vandenberg JD, Fichter BL, Lahm G (1982) Inhibition of chalkbrood spore germination in vitro. Bull 656, Oreg State Univ Agric Exp Stn, Corvallis, OR

Stephen WP, Vandenberg JD, Fichter BL (1981) Etiology and epizootiology of chalkbrood in the leafcutting bee, Megachile rotundata (Fabricius), with notes on Ascosphaera species. Bull 653, Oreg State Univ Agric Exp Stn, Corvallis, OR

Vandenberg JD, Fichter BL, Stephen WP (1980) Spore load of Ascosphaera species on emerging adults of the alfalfa leafcutting bee, Megachile rotundata. Appl Environ Microbiol 39, 650-655

Vandenberg JD, Stephen WP (1982) Etiology and symptomatology of chalkbrood in the alfalfa leafcutting bee, Megachile rotundata. J Invertebr Pathol 39, 133-137

Vandenberg JD, Stephen WP (1983) Pathogenesis of chalkbrood in the alfalfa leafcutting bee, Megachile rotundata. Apidologie 14, 333-341

Youssef NN, Brindley WA (1989) Effectiveness of Botran and DPX 965 as growth inhibitors of Ascosphaera aggregata (Ascosphaeraceae) in the alfalfa leafcutting bee (Hymenoptera: Megachilidae). J Econ Entomol 82, 1335-1338

Youssef NN, McManus WR (1985) Captan: a promising fungicide for management of chalkbrood diseases in the alfalfa leafcutting bee. J Econ Entomol 78, 428-431 